\title{
wan \\ Daoism and the Operation of the Eastern Stronghold Temple in the Late Imperial China
}

\author{
Zhaojie Bai ${ }^{1, *}$ and Teng Yao ${ }^{2}$ \\ 1 Institute of Philosophy, Shanghai Academy of Social Sciences, Shanghai 200051, China \\ 2 Department of History, Xinzhou Teachers University, Xinzhou 036199, China; xztuyaoteng@163.com \\ * Correspondence: bzj@sass.org.cn
}

Citation: Bai, Zhaojie, and Teng Yao. 2022. Daoism and the Operation of the Eastern Stronghold Temple in the Late Imperial China. Religions 13: 159. https://doi.org/10.3390/ rel13020159

Academic Editor: Jinhua Jia

Received: 7 January 2022

Accepted: 7 February 2022

Published: 11 February 2022

Publisher's Note: MDPI stays neutral with regard to jurisdictional claims in published maps and institutional affiliations.

Copyright: (c) 2022 by the authors. Licensee MDPI, Basel, Switzerland. This article is an open access article distributed under the terms and conditions of the Creative Commons Attribution (CC BY) license (https:/ / creativecommons.org/licenses/by/ $4.0 /)$.

\begin{abstract}
The sacrificial ritual to Mount Yi (Yishan 沂山) or the Eastern Stronghold (Dongzhen 東 鎮) was included in the traditional Chinese state ritual system to mountain and water gods, and therefore, originally, it was a Confucian ritual. The Eastern Stronghold Temple was operated by officers and clerks appointed by the government. However, during the late imperial period, the situation changed and the Eastern Stronghold Temple became virtually operated by Daoism, mainly because of the government's difficulty in maintaining the temple, the growth and power of Daoism, especially the Complete Perfection Daoism popular in northern China, and the further integration of Confucianism, Daoism, and folk beliefs. Daoist priests, who were named "temple guardians", took responsibilities for guarding temple property, coordinating central and local government's sacrificial rituals, administrating the daily operation of the temple, conducting reconstruction projects, and incorporating local people's beliefs. As a result, the temple not only served as an official place of worship but also gained the functions and identity of a Daoist abbey and folk temple. As the first article discussing the Eastern Stronghold Temple in a western language, this study mainly applies the rediscovered source of stone inscriptions preserved in the temple to describe Daoism's contributions to this religious-political-cultural symbolic site and the complicated relationship between governmental officials, Daoist priests, and local people.
\end{abstract}

Keywords: Mount Yi; Eastern Stronghold Temple; state sacrifice; Daoism; Complete Perfection Daoism

\section{Introduction}

Mount Yi (Yishan 沂山), located in today's Weifang 濰坊 city of Shandong 山東 province, was also named the Eastern Stronghold (Dongzhen 東鎮) and included in the traditional Chinese state ritual system to mountain and water gods, namely, the Five Sacred Peaks (Wuyue 五岳), Five Strongholds (Wuzhen 五鎮), Four Seas (Sihai 四海), and Four Waterways (Sidu 四瀆) (Jia 2021). Since the Sui and Tang dynasties (581-907), the Eastern Stronghold Temple (Dongzhenmiao 東鎮廟) was established on Mount Yi and became the sacred site for holding sacrificial rituals to the god of Mount Yi (Zhang 2011; Liang 2013).

The state sacrificial system to mountain and water spirits was originally a Confucian ritual, and, as a national sacrificial temple with symbolic significance of political rule, the Eastern Stronghold Temple was originally operated by officers and clerks appointed by governmental authorities. However, recent studies have pointed out that since the Jin (1115-1234) and Yuan dynasties (1271-1368), Daoists played important roles in the maintenance of the five national stronghold temples (Ma 2011, pp. 15-16; Lin 2017, pp. 105-11), including the Eastern Stronghold Temple. Officially, the temple retained the title of "national sacrifice site", but the daily operations were left to the care of Daoist priests, who were named "temple guardian". The reasons for this important change may be observed from three aspects. First, Daoism had developed strongly and permeated people's daily life, especially the Complete Perfection Daoism in northern China. Second, the imperial government both restricted 
and used Daoism for political purposes. Third, the religious-cultural integration of Confucianism, Daoism, Buddhism, and folk beliefs had further developed during the late imperial period.

As far as the above issues are concerned, the daily operation of the Eastern Stronghold Temple is an exemplary case study, which provides the opportunity to see the role Daoism played in such a major national sacrifice temple. What kind of position did it occupy? What changes had it brought to the functions of the national sacrifice beyond the expectations of the imperial court? In order to uncover reliable answers to such questions, it is first necessary to retrace the historical details of Daoism at the Eastern Stronghold Temple.

There have been some studies of the Eastern Stronghold, but mostly they have focused on the official ritual system and sacrificial practices, and few scholars have devoted their time to the subject of guardian Daoist priests. Presumably, the main reason for this is the lack of first-hand successive references and the available sources are too fragmented. The records of Daoism at the Eastern Stronghold in local chronicles are quite scattered. Thus, given the insufficiency of available materials, it is necessary to find new materials to get a fresh perspective in the study on Daoism. Fortunately, in recent years, new findings and compilations of the stone inscriptions preserved in Mount Yi have made it possible to further study the history of Daoism in the Eastern Stronghold (Zhao and Gong 2011). These stone inscriptions were mainly inscribed during the Yuan, Ming and Qing dynasties. It is believed that there were more than 360 ancient steles in the temple until 1904, but there are now only about 145 left (Zhang 2009, pp. 14-15; Zhang and Wang 2001, pp. 41-42). Still, compared with other available materials, these inscriptions reveal a lot about Daoism of the Eastern Stronghold. Based on the evidence of these inscriptions, combined with local chronicles and official histories, this paper first discusses the essential situation of Daoism in the Eastern Stronghold Temple during the Yuan, Ming, and Qing dynasties. It then uses the construction and reconstruction cases of the Eastern Stronghold Temple as examples to demonstrate the contributions of Daoism to the maintenance of the temple and its manifold influence in general.

\section{Overall Situation of Daoism in the Eastern Stronghold Temple}

At sacrifice sites of sacred peaks, strongholds, seas, and waterways in the Tang and Song dynasties, temple directors or other post-holders were instructed on duty, and the sacrificial works were carried out by county magistrates, retired state officials, or county directors. However, according to the current information available, the daily affairs of the Eastern Stronghold Temple were managed by Daoist priests from the Jin Dynasty. In 1173, the temples of the mountain and water gods were then converted to be left under the care of Daoist priests (Liang 2013, p. 50; Zhao 2020, pp. 51-55). The Daoist management of these temples originated from a reform carried out in the Zhongyue 中岳 Temple (Middle Sacred Peak, Mount Song 嵩山) to prevent low-ranking officials from misappropriating the charitable donations of common people intended for blessings and prayer. From then on, "The sacrificial rituals of the Middle Sacred Peak Mount Song follow the old way and order of Daoist priests from Chongfu Palace to preside over" 嵩山中岳祈依舊令本處崇福宮道士看守， according to an official reaction of the imperial court, which later became an example for any other temples of mountain and water gods "supervised by two prominent Daoist priests selected by the local government from where the temples belonged" 委 所隸州府選有德行名高道士二人看管 (Ren 2019, 34.337). During the Mingchang 明 昌 period (1190-1196), the central Government bestowed the gods of the strongholds and waterways with the titles of king after accepting the advice of the Daoist priest Yang Daoquan 楊道全. (In particular, the God of the Eastern Stronghold was titled Donganwang 東安王, the East-Protection King). Yang was from Mount Yi (Toqhtō 1975, 34.810) whose cave the stele partly quoted in the "Shenyougong ji" 神祐宮記 
(Account of Divine Protection Palace) of the Eastern Stronghold Temple. In this quotation, the Daoist priest was signed as "Yang Daoquan, the Daoist priest and preaching master who was in charge of the Temple" 知廟道士傳度師楊道全 (Zhao and Gong 2011, p. 8). Therefore, we know that the Eastern Stronghold Temple was indeed handed over to the Daoist priests by this time. In 1173, there were only two Daoist priests entrusted with guardian positions, but the number was soon allowed to be expanded because of the overloading of affairs (Ren 2019, 34.337). According to the record of stele inscriptions, it is known that the number of Daoist priests in the temple increased rapidly after the establishment of the Temple. For example, inscriptions such as “Dongzhen Yishan Yuande Donganwangmiao Shenyougong ji" 東鎮沂山元 德東安王廟神佑宮記 (Account on the Divine Protection Palace of the Temple of PrimeVirtue Eastern-Protector King of Mount Yi the Eastern Stronghold, and abbreviated as the "Account of Divine Protection Palace"), carved in 1322, "Chongxiu Dongzhen Yishan miaoji" 重修東鎮沂山廟記 (Account on Reconstruction of Mount Yi the Eastern Stronghold Temple), carved in 1614, the "Chongxiu Dongzhenmiao luochengji" 重修東鎮廟落成記 (Account on the Completion of the Reconstruction of the Eastern Stronghold Temple), carved in 1663, and the Yellow Booklet (Registration Manual of Populations) during the Qianlong 乾隆 period (1736-1795) of the Qing Dynasty, and so forth (Qin 2014, p. 193), all serve to illustrate this point. There were at least 36 Daoist priests in the Eastern Stronghold Temple from 1573 to 1620 during the Ming Dynasty. However, the number of Daoist priests continuously decreased during the Qing Dynasty. In the early years of the Qianlong period, there were at most 16 Daoist priests, but only a few were still there after the Guangxu 光緒 period (1875-1908). The obvious fluctuation in the number of Daoists reflects the historical trend of the rise and fall of Daoism in the Eastern Stronghold Temple. At the same time, it also indicates the rise and fall of the court's attention to the local temples that once symbolized its dominance.

\subsection{Sect Affiliations of the Daoists in the Eastern Stronghold Temple and Their Relationship with Local Daoist Bureaus}

Zhao Weidong 趙衛東 has paid attention to the Daoist inscriptions in the Eastern Stronghold, especially those referring to a master-apprentice relationship, such as Tang Jiaoyu's 唐教玉 tombstone and Zhao Shoushen's tombstone. After he compared the sect-names with the Daoists of the Complete Perfection Dao (Quanzhendao 全 真道) recorded in the Zhuzhen zongpai zongbu 諸真宗派總簿 (General Book of All Daoist Sects), Zhao believed that the Eastern Stronghold Daoists during the Yuan Dynasty belonged to the Complete Perfection, but their sub-branching sect is still unknown. From the end of the Jiajing 嘉靖 Period of the Ming Dynasty (1522-1566), it was obvious that the Mount Hua Sect (Huashanpai 華山派) and Patriarch Qiu's Extra Sect (Qiuzu youpai 丘祖又派) coexisted in the temple, and the latter was established by Tang Jiaoyu, who was once a disciple of the former sect (Zhao 2014b, pp. 274-89).

According to the information aforementioned, during the Jin Dynasty, the Daoist priest Yang Daoquan from the Eastern Stronghold was titled as a "preaching master" (chuandushi 傳度師). Therefore, it is reasonable to predict that the Eastern Stronghold Daoists belong to Zhengyi Dao 正一道 and that the Complete Perfection Daoists came to the Eastern Stronghold Temple probably from the time of the Yuan Dynasty. The "Account of Divine Protection Palace", dated from 1322, is rich in information and worth close attention. According to the inscription, Mei Daoyin 梅道隱 once served as the Abbot (tidian 提點) of the Eastern Stronghold Temple. After the Official Sacrifice in 1298, Mei was rewarded as the Arch-Abbot of the Extreme Void Palace (Taixugong 太虛宮) of Yidu 益都 Circuit (in present-day Qingzhou 青州, Shandong). When he was promoted, Mei recommended Zhang Dexian 張德顯 to be the abbot of the Eastern Stronghold Temple and to hold his previous position (Zhao and Gong 2011, p. 8). The next year, the Grand Master President of National Daoism (zhangjiao dazhenren 
掌教大真人) formally appointed Zhang Dexian as “Daoist on Duty of the Divine Protection Palace in Eastern Stronghold of Mount Yi, in Charge of the Temple of PrimeVirtue Eastern-Protector King" 東鎮沂山神佑宮提點勾當, 知元德東安王廟事. During his official term, Zhang Dexian actively built the Divine Protection Palace, but died soon after. As his successor, the abbot of the Extreme Void Palace, Tang Zhiqian (唐志 遷), took charge of temple affairs and presided over the completion of the construction project. After his promotion to Extreme Void Palace, Mei Daoyin, who once served as an abbot in the Eastern Stronghold, was bestowed with the titles of Master of Tranquil Perfection and Pure Virtue (zhenjing chunde dashi 真靜純德大師), the Provincial Daoist Magistrate (benlu dudaolu 本路都道錄), and both the Abbot of the Eastern Stronghold and Extreme Void Palace. However, Mei's name can still be found in the inscription of “Tuohuan Cai Wenyuan zhaogaobei” 脱歡, 蔡文淵昭告碑 (Tuohuan and Cai Wenyuan's Proclaiming Stele) dating from 1313, which hints that after he was promoted to the Extreme Void Palace in 1298, Mei once again served as a guardian Daoist in the Eastern Stronghold Temple for some time (Zhao and Gong 2011, p. 6). As Zhao Weidong said, this inscription shows the close relationship between the Divine Protection Palace, the Extreme Void Palace, and the Eastern Stronghold Temple (Zhao 2014a, p. 3; 2014b, p. 285). Based on the inscription "Qingxu chunde fujiao zhenren citang ji" 清虛純德輔教真人祠堂記 (Account of the Ancestral Hall of the Realized Person of Clear Void, Pure Virtue, and Doctrinal Promoter Daoist), the Complete Perfection Daoist Patriarch Qiu Chuji 丘處機 once performed his monastic practice in the Extreme Void Palace of Qixia (present-day Qixia 棲霞, Shangdong), while the Extreme Void Palace of Yidu 益都 Circuit (present-day Qingzhou, Shandong) was built by Qiu Chuji's disciple Fan Quansheng 范全生, who purchased Magistrate Xu's residence and reconstructed it into a Daoist temple. Accordingly, the two Extreme Void palaces might have formed a relationship between the superior and subordinate (Wang 2005, pp. 40-41). Since the reign of Kublai Khan (1260-1294), a customized system of Daoist management had been in place, including the Daoist Registration Bureau (daosusi 道錄司) set under the circuit (lu 路) government, the Daoist Direction Bureau (daozhengsi 道正司) at the prefecture level, and the Prestige Bureau (weiyisi 威儀司) under the county (Cheng 2012, pp. 122-30). Based on the information seen so far, it is speculated that the Daoist Registration Bureau of the Yidu Circuit during the Yuan Dynasty was likely located in the Extreme Void Palace. Given the administrative relationship between the Extreme Void Palace of the Yidu Circuit and the Eastern Stronghold Temple, this palace could send Daoist priests to the Eastern Stronghold Temple, and even entrust Daoists to run the National Sacrifice. However, the Eastern Stronghold Temple was a national-level sacrifice site, and it was impossible for the Extreme Void Palace to be formally accepted as its own subordinate temple; consequently, the construction of an exclusive Daoist Hall in the temple had become a convenient measure for Daoist priests to live and manage.

Therefore, the intervention of the Extreme Void Palace and Daoist Registration Bureau of the Yidu Circuit could be seen as a watershed in the history of the development of Daoism in the Eastern Stronghold Temple, while the establishment of the Divine Protection Palace could be regarded as a symbol of the extensive development of Daoist groups in the Eastern Stronghold Temple. The institutional relationship between the temple and the palace was the necessary foundation that allowed the Complete Perfection Daoism of the Extreme Void Temple to spread smoothly in the Eastern Stronghold Temple, which ultimately led to the conversion of the Eastern Stronghold Temple to Complete Perfection Daoism. After 1369 (the second year of the Hongwu 洪武 period of the Ming Dynasty), the existing Eastern Stronghold inscriptions show that the temple was no longer related to the Extreme Void Palace. According to the Jiajing qingzhoufu zhi 嘉定青州府志 (gazetteer of Qingzhou compiled in the Jiajing Period), the Extreme Void Palace had already been changed to a Confucian temple (Feng 2014, 7.32). From 1406 to 1465, during the early Ming Dynasty, the priests from the 
Daoist Assembly Bureau (daohuisi 道會司) took the place of Extreme Void Palace to participate in the official sacrificial activities of the Eastern Stronghold Temple.

The Daoists Assembly Bureau was a county-level Daoist administrative organization established in 1382 (Liu 2017, pp. 73-84). The Daoists Assembly Bureau of Linqu County, during the early Ming Dynasty, was placed in the Ziwei Guan 紫微 觀 (Purple Sublimity Abbey), built in the Zhongtong 中統 period (1260-1264) of the Yuan Dynasty, and the local Daoist Bureau was set up inside it during the Yuan Dynasty. From the Ming Dynasty to the Qing Dynasty, the Daoists Management Bureau of Linqu had been settled in this abbey for a long time (Wang 2002, 2.14 and 4.27; Yin 2002, 1.50 and 2.54). By the end of the 19th century, during the reign of Guangxu (1875-1908), there was not a permanent temple of operations for the Daoist Assembly Bureau of Linqu (Yao 2002, 5.147). Moreover, no signatures of the Daoist Assembly Bureau priests can be found in the stone carvings of the Eastern Stronghold Temple from 1467 (the third year of the Chenghua 成化 period of the Ming dynasty) to the end of the Qing Dynasty. The absence of the signatures, however, does not mean that the Daoist Assembly Bureau of Linqu County disappeared completely; rather it shows that the Bureau's power had declined in influence and status, while at the same time the Daoist priests in the Eastern Stronghold Temple had restored their self-governing positions.

\subsection{Political Status of Daoist Priests in the Eastern Stronghold Temple}

From the Yuan Dynasty to the Qing Dynasty, the political status of Daoist priests in the Eastern Stronghold Temple gradually declined. As mentioned previously, from the Yuan Dynasty to the Hongwu period (1368-1398) of the Ming Dynasty, the Eastern Stronghold Temple may have been entrusted to the Extreme Void Palace, and some of the Daoists in charge of the Eastern Stronghold Temple had a relatively high political status. Take Mei Daoyin as an example, whose name appears in numerous carved records of the Yuan Dynasty, including two stele inscriptions in particular, “Chongjian haotiangong bei" 重建关天宮碑 (Rebuilding the Haotian Palace) (Zhao and Zhuang 2010, p. 349) and “Dayuan jiang yuxiang zhiji” 大元降御香之記 (Account of Bestowing Incense by Great Yuan) (Zhao and Zhuang 2010, p. 350), both of which were memorial monuments to the Eastern Stronghold. In addition, Mei also participated in the Daoist activities in Qingzhou as the Daoist Judge (daopan 道判) and the Daoist Register (dudaolu 都道錄) of Yidu Circuit. Throughout the Ming Dynasty, although there are no material records of the Eastern Stronghold Daoist priests being local Daoist officials, the Eastern Stronghold abbots could still formally participate in the official sacrificial activities and engrave their names on the relevant inscriptions. During the reign of Emperor Kangxi 康熙 (1662-1722) of the Qing Dynasty, Daoists in the Eastern Stronghold Temple could still keep their positions as they had during the Ming Dynasty. In any event, after Kangxi's reign there were no longer Daoist priests of the Eastern Stronghold Temple who signed their name on a large number of official sacrificial inscriptions. This phenomenon reflects the intention of the rulers of the Qing Dynasty to exclude Daoism from the national sacrificial rites and suppress the power of Daoism more generally.

As is well known, the Daoist priests had a certain obligation to maintain the Eastern Stronghold Temple but could not get direct economic benefits from official sacrifices. In 1335, Liu Sicheng 劉思誠 recorded that on the eve of offering sacrifices to the Eastern Stronghold, "(The government officials) ordered Daoists to ring bells and drums, to arrange the ceremony with setting sacrificial utensils and presentations" 遂命道士鳴鐘鼓，列樽俎醮事焉 (Wang 2003, 4.138). Since there are some sacrificial utensils, such as iron pots, tables and chairs, preserved in the Eastern Stronghold Temple (Wang 2003, 1.124), it is reasonable to speculate that Daoist priests had been involved in the national sacrifices for a long time. However, taking as an example the prescribed cost of sacrifice in the Eastern Stronghold given by the local chronicles of 
Linqu in the Qing Dynasty, we find that the annual expenditure on sacrifice allocated by the county government was only about 10 taels of silver (Qingzhou Prefecture Authority, Shandong Province 2003, p. 228; Yao 2002, 6.157). Obviously, based on such a small amount, the Daoist priests in the Eastern Stronghold Temple could not have gotten any profit from it. From the point of view of the governmental authorities, the Daoist priests mainly acted as the voluntary guardians of the official temple of the mountain.

Based on the evidence above, the evolution of Daoism in the Eastern Stronghold Temple and the attitude of the central government towards this Daoist group in different periods have both been sufficiently demonstrated. The new information is essential for understanding how the Daoist group operated the Eastern Stronghold Temple. Divergent from the rising trend of Daoism in the Eastern Stronghold Temple during the Yuan Dynasty, the lack of daily management and marginalization of Daoists during the Ming and Qing dynasties prompted the move toward self-operation. While the Daoists assumed more and more responsibility for the temple, they also gained the power and ability to freely interpret and practice Daoism in this temple. This point has been partially demonstrated in several important construction activities in the history of the Eastern Stronghold Temple.

\section{Government, Daoists, and Local People: Guardian Daoist Priests and Constructions of the Eastern Stronghold Temple}

As the most important official sacrifice in Linqu and even Qingzhou, the Eastern Stronghold Temple should have been paid special attention to by local governments, but it was often unable to be preserved for various reasons. Words similar to those in “Linquxian chongxiu dongzhenmiao ji” 臨朐縣重修東鎮廟記 (Account on Rebuilding the Temple of the Eastern Stronghold in Linqu County) in 1569 are common:

Our Ming dynasty has bestowed Yishan with an appropriate title, offered sacrifices with piety, reconstructed the temples and made them magnificent in scale. However, after many years, the wooden buildings began to brake and were hard to repair. Since xinmao year of Jiajing (1531), the temple has been nearly in ruins, and the orthodox regulations were also abandoned. Because of the lack of finances, it remains only a small room for the god, which is far from fitting the regulations. 我明厘正封號, 虔祀有加, 廟貌崇嚴, 規制大備. 第時久就廢, 修建維熯. 入嘉靖辛印以來, 廢殆極矣, 而正典亦廢. 絀 于財力, 僅成類小室者以奉主位, 大不稱制. (Wang 2003, 4.144-145)

According to Linquxian fuyi quanshu 臨朐縣賦役全書 (Comprehensive manual of Linqu taxes and corvée; 1657) and the Linqu xianzhi 臨朐縣志 (Chronicles of Linqu County; 1884), the financial revenue of Linqu County did not have a budget specifically used to maintain the construction of the Eastern Stronghold. One reason for the lack of efforts on the part of the Linqu government may have been that the location of the Eastern Stronghold Temple was too remote. The Eastern Stronghold Temple is located in the foothills of Yi Mountain, which is nearly a hundred $l i$ 里 (Chinese miles) away from Linqu city. For the Linqu government, this national sacrifice temple was not only located on the outer edge of space but also on the edge of society. Negligence had become a reasonable strategy to save on the cost of governance. In fact, during the Ming Dynasty, according to "Chongxiu weisushan dongzhen xinggong ji" 重修 委粟山東鎮行宮記 (Account on Rebuilding the Residence of the Eastern Stronghold on Weisu Mountain), it was precisely because the Eastern Stronghold Temple was so far away that the people of Linqu County built the Eastern Stronghold Residence on Weisu Mountain, approximately three li northeast of the county town, around 1580, to avoid undue the hardship of a long journey (Wang 2003, 4.145-146). As it was far away from the protection of the county government, the Eastern Stronghold Temple was often harassed by bandits who gathered in Yishan. The fear of bandits who often appeared in the Yishan area and that temples might be ransacked and de- 
stroyed also deepened the local government's misgivings about subsidizing the Eastern Stronghold Temple.

Obviously, the maintenance of the Eastern Stronghold Temple needed to rely on other forces outside the government. In fact, the people most concerned about the appearance of the Eastern Stronghold Temple were likely the temple-guarding priests who lived there. Judging from the inscriptions of the steles in the temple, the Daoists certainly hoped that the authorities would give enough support to ensure the integrity of the temple, but when the authorities were unable to meet their requirements, it became more pragmatic to join forces with the local folk forces, including the elders and gentry. At the same time, the local people had a belief in the God of Mount Yi and were willing to participate in the maintenance of the temple as much as they could, so as to win divine protection for themselves and their community, strive for honor and "semi-official" power, and achieve the goal of strengthening community cohesion and local power.

As a result, the Eastern Stronghold Temple, where Daoist priests maintained the operations, had become a field of intertwined relationships between the central government, local governments, and Daoist and folk organizations, and the temple construction activities themselves had become a typical situation representing these complex relationships. The following examples show how Daoist priests played an important role in the construction of the Eastern Stronghold Temple.

\subsection{The Construction of the Divine Protection Palace in Yuan Dynasty}

According to the "Account of Divine Protection Palace" of 1298, the god of Yishan was bestowed with the title of Prime-Virtue Eastern-Protector King by the central government. Those who participated in the bestowal-sacrifice are found named on an old stele in the temple, which records that "the Divine Protection Palace on the right of the temple, is the place where Daoist priests of the temple attend and worship" 廟 之右神佑宮者, 乃知廟道士參禮之所也 (Zhao and Gong 2011, p. 8). In the next year, 1299, Zhang Dexian was officially appointed to be responsible for the management of the Eastern Stronghold Temple and Divine Protection Palace. This appointment was by Zhang Zhixian 張志仙, the President Daoist (zhangjiao 掌教) in charge of National Complete Perfection Daoism (1224-ca. 1308; his term of office was 1285-1307) (Cheng 2012, p. 29). The President Daoist in the Yuan Dynasty was privileged to offer sacrifices to mountain and water gods as the deputy of the monarch and also obtained the power to appoint the person in charge and the temple abbots (Cheng 2012, p. 127). After his appointment, Zhang Dexian started the restoration of the Eastern Stronghold Temple and the construction of the Divine Protection Palace, but unfortunately died soon after. Then, Tang Zhiqian 唐志遷 was appointed to become his successor and eventually led the reconstruction to its completion.

According to the main content on the front of the stele, although this repairing activity got a little support from local officials, it was mainly a project conducted by Daoists in the Eastern Stronghold Temple and the Extreme Void Palace. On the back of the stele, numerous local common people's names were engraved following the signatures of the stonemason and calligraphy writers whose names should be at the end of this stele. It suggests that the inscriptions on the stele were carved at least twice, and the local people, inspired by Daoists, actively participated in the construction of the Divine Protection Palace and the Eastern Stronghold Temple. Moreover, on the steles of “Li Mu daisi bei" 李木代祀碑 (Sacrifice Hosted by Deputy Li Mu), of 1465, “Chongxiu Dongzhenmiao jibei" 重修東鎮廟記碑 (Account of Reconstruction of the Eastern Stronghold), of 1467, and “Li Xi'an daisi bei” 李希安代祀碑 (Sacrifice Hosted by Deputy Li Xi'an), of 1470, the term "abbot of Divine Protection Palace" 神佑宮住 持 was replaced by "abbot of this temple" 本廟住持 (Zhao and Gong 2011, pp. 32, 35, 37). In light of the fact that there was no longer any mention of the Divine Protection Palace appearing in the local chronicles and stone inscriptions of Yishan and Linqu 
during the Ming and Qing dynasties, it could potentially be concluded, or at least speculated, that the Divine Protection Palace was abolished before the Chenghua period (1465-1487) of the Ming Dynasty.

\subsection{The Constructions in 1556-1561 and 1614 of the Ming Dynasty}

The bandit problem in Yishan was serious, so it became a special function of Yishan God to help the official forces in suppressing the bandits with divine power. The “Dongzhen xiuwadian ji” 東鎮修瓦殿記 (Account of Building the Brick Hall in the Eastern Stronghold), in 1159, recorded a miracle: during the Fuchang 阜昌 period (1130-1137) of the Puppet-Qi Administration, the fierce outlaw Lei Zhen 類㮹 gathered his bandits in the mountain. However, after the local official Tian Shaozu $⿴ 囗 十$ 紹祖 wrote a poem on the wall of the Eastern Stronghold Temple, the bandits were defeated by local forces (Yao 2002, 9.179). A similar story inexplicably occurred once again during the Ming Dynasty and may have been what led to the reconstruction of the Eastern Stronghold Temple.

According to Wang Juyi's “Dongzhen miekou ji” 東鎮滅寇記 (Record of the Destruction of Bandits in the Eastern Stronghold), Zhao Ci 趙慈 and his bandits raised a rebellion in 1552. Zhao had consulted the divination lottery in the Eastern Stronghold Temple before attacking the city of Linqu, but all three lots presaged a disastrous result and he went away angry. No further than five kilometers from the temple he encountered government forces. During the battle, the wind changed suddenly, which was beneficial for the officials, and the bandits were roundly defeated. Later, the official army interrogated the captives, who said they saw the God of the Eastern Stronghold help the official army fight and this was the reason for their defeat (Wang 2003, 4.143; Fu 2003, 8.57). Perhaps the revelation of God on Mount Yi inspired the local people to rebuild the Eastern Stronghold Temple to repay his grace. For this reconstruction, Wang Juyi wrote the "Chongxiu Dongzhenmiao yuan buyin" 重修東鎮廟緣簿引 (Accounts of the Reasons for the Reconstruction of the Eastern Stronghold Temple). In this record, Wang said that the Eastern Stronghold Temple at that time was falling apart, the main hall, the dormitory, the corridor, and even the steles were in a dilapidated state (Wang 2003, 4.143-144). In fact, Linqu biannianlu 臨 朐編年錄 (Chronicle of Linqu) mentions that a small hall had been built for the Eastern Stronghold Temple seven years before (1549) by Wang Jiashi 王家士, the Magistrate of Linqu County (Zhang 2003, 6.197). Wang Jiashi's Jiajing Linquxian zhi 嘉靖臨朐縣 誌 (Linqu County Gazetteer, complied in the Jiajing period) also recorded his repair activities, saying that the Eastern Stronghold Temple was "decadent for a long time" 歲久傾頽, "but since giant wood is rare to find, and the sacrificial ceremony of the Stronghold Temple is different from other constructions, to renovate the temple has to wait for cooperative completion with neighboring counties in a harvest year" 但巨 木難得. 鎮廟祀典非他興作可擬, 煥然鼎新, 固有待於豐年鄰邑共成之力也 (Wang 2002, 2.13). It is clear that the Eastern Stronghold Temple was dilapidated, yet the local government was unable to maintain it, and this was a difficult problem that had existed for a long time. Wang Juyi attributed the crippling of the Eastern Stronghold Temple to the inaction of the government: "Likely those above were conservative in accordance with the rules, and thus those below abandoned their duties" 盖上既狃于 因循, 斯下遂成夫玩愒. “Although the grains in sacrificial utensils are pure in spring and autumn, the building no longer appears magnificent and glorious" 粢盛雖潔於 春秋，壯麗難憑乎輪爫 (Wang 2003, 4.143-144). Obviously, Wang Juyi was criticizing the official use of the Eastern Stronghold Temple as an occasional place of sacrifice but did not care about the operation and renovation of the Temple. Disappointment with the local government made Wang Juyi and other local gentry who felt concerned about the temple turn to common people for help:

To accumulate little by little, we must ask for help from neighboring towns; to cut the long to amend the short, we have to rely on people of all directions. 
Therefore, we wholeheartedly pray for mutual assistance. No matter you are rich or poor, please contribute according to your own possessions; no matter wise or foolish, please help according to your own heart. 但積少成多，必旁 求乎列邑; 而絶長補短, 須仰賴於十方. 為此, 竭誠專祈共濟. 或貧或富, 量所有 以相周; 無智無愚, 隨其心而協助. (Wang 2003, 4.143-144)

As recorded in the Kangxi Linquxian zhi 康熙臨朐縣誌 (Linqu County Gazeteer, complied in the Kangxi Period), the reconstruction of the Eastern Stronghold Temple in 1676 received a variety of sponsorship from the "righteous people" of Linqu County (Yin 2002, 4.87). The reconstruction began soon after Zhao Ci and his bandits were defeated by the local government. In any event, since the local government was still under pressure in terms of finances to maintain stability, it might have been unwilling to pay a high price to organize the engineering activity. However, the prevarication of the Linqu County government gave an opportunity for folk groups to enter the Eastern Stronghold Temple in an organized and large-scale manner. It is easy to understand that when the government was absent in its temple-managing responsibility, it transferred its privilege to the public. However, this reconstruction might not have been a substantial one because of the financial restrictions and the temporal proximity of the bandit disasters. Since the reconstruction happened only one year later, the local societies that had experienced outlaws attack also needed time to heal their wounds.

In 1558, the thirty-seventh year of the Jiajing period, the Daoist priest of the Eastern Stronghold Temple played the leading role in the year's restoration. The “Chongxiu Dongzhenmiao timing ji” 重修東鎮廟題名記 (Record of the Names Signed on the Stele of Rebuilding the Eastern Stronghold Temple), which was established in 1561, indicates the fact of the event:

In recent years, the buildings in the Eastern Stronghold have been devastated by wind and rain, and the gods' statues exposed to air. The Daoist abbot of this temple, Tang Jiaoyu, and other related Daoists once presented the situation to the county government, and the local government also informed the Military Defense Circuit Office, who issued the order to allow Daoists to raise donated money and food from people of all directions. And the two county governments of Linqu and Yishui served as supervisors and dispatched laborers to rebuild the residence hall of five columns using glazed tiles with forged beasts, two porticos of ten columns, and one Lingxing Gate. The reconstruction began in the thirty-seventh year and was completed in the fortieth year of Jiangjing Period. 東鎮廟宇, 近年以來, 風雨摧殘, 神像暴 露, 本廟住持唐教玉等, 具呈到縣, 轉申本府兵備道給印信, $\square \square$ 緣募四方錢糧. 臨朐沂水二縣城, 夫役督工, 修理寝殿五楹,具用琉璃瓦獸, 兩痖十楹,靈星門一 座. 自嘉靖三十七年起工, 至四十年落成. (Zhao and Gong 2011, p. 78)

The local governments, including Linqu County, Yishui County, and even the Qingzhou Superior Prefecture, seemed to encourage and support the restoration of Daoist Tang Jiaoyu. However, in addition to allowing the fund-raising behavior of Tang Jiaoyu, the local government mainly exercised the obligation of "supervision," and those who authentically put their energy in the restoration were the group of Daoists, such as "Daoist Chen Chongjin, fund-raising abbot Tang Jiaoyu, Donators Du Jiaoyong, Huan Yilin, Wang Jiaohong, Li Jiaoyun, Meng Daosheng, Shen Daogui" 道士陳崇進, 募緣住持唐教玉, 助緣杜教用，邭一林，王教洪，李教允，孟道勝，申道貴 and “abbot Cui Chongyou" 住持崔崇祐. The independent fund-raising behavior of Tang Jiaoyu showed that the Daoist priests in the Eastern Stronghold no longer placed all the obligations of maintaining their temple on the local government, but the official who "issued the order" could overlay the essentially non-governmental fund-raising activities with some sense of official support, and it was helpful to win the generous support of local officials and gentry. According to the inscription on this stone, the strategy achieved 
the desired results, and many local officials participated, making donations in their personal capacity, while at the same time villagers in Linqu, Yishui 沂水, and Changle 昌樂 also unpacked their bags to donate.

Unfortunately, the four-year reconstruction still failed to completely solve the problems of the dilapidated Eastern Stronghold Temple. Meng Yangxing's 孟養性 "You Yishan ji" 遊沂山記 (Account of Visiting Yishan) recorded that, in 1562, the Eastern Stronghold Temple was "small and not fit for a divine residence" 殿宇狭小, 不 称神居. Regarding this situation, the Daoist priest in the temple explained: "according to the regulation, this temple should be a high-level building with big and wide space, and of construction almost equal to the temple of the sacred peak Taishan, but it has been dilapidated for a long time. Although the site is preserved, huge woods are hard to come by, and the labors needed are so large that it would be hardly restored without provincial level cooperation" 庙制高阔, 原见视泰岳, 岁久圮废. 遗址虽 存，巨木难受，工役之大，非通省协力莫能复也 (Wang 2003, 4.144). In any case, the reconstruction activities from 1558 to 1561 still reveal important information about the Eastern Stronghold Temple. Firstly, from an institutional view, the temple guardian Daoists had no obligation to make excessive efforts for the maintenance of the Eastern Stronghold Temple and it was to be the officials' duty to repair the national sacrifice temples. In reality, though, the government was often uninterested and incapable of properly dealing with the temples, so the Daoist priests who lived in them had to bear some of the responsibilities. While assuming responsibility, these guardian Daoist priests also reasonably gained the power to operate the Eastern Stronghold Temple with flexibility, as can be seen in their control over holding ritual offerings 醮 in the temple, which will be further discussed later. Secondly, the completeness or decay of the temple directly affected the living situation of the Daoist priests in the temple, but they did not have sufficient funds to maintain such a huge temple, so it was inevitable to strive for the sponsorship of the government and non-governmental forces. When there was no official support, the cooperation between temple guardians and folk forces became particularly important in maintaining the temple. At the same time, the folk forces-represented by the gentry and rural elders-also obtained an opportunity to enter the Eastern Stronghold Temple and made a far-reaching impact on the temple. It must be admitted: the reconstruction activities led by Tang Jiaoyu revealed that none of the officials, Daoists, or folk forces could provide proper protection for the Eastern Stronghold Temple for long, and for this reason the normal operation of the temple was barely maintained after the middle of the Ming Dynasty. The cooperation and prevarication among the three parties in the renovation effort and the change of actual control contributed to the uncertain identity of the Temple. For the purposes of different groups, the Eastern Stronghold Temple was not only a national temple to enjoy the institutional sacrifice of the court but also a legitimate Daoist abbey and a folk temple of local beliefs.

Since the reconstruction project at the end of the Jiajing period (1522-1566) of the Ming Dynasty, it had become regular practice for the government, Daoists, and folk elites to cooperatively repair the Eastern Stronghold Temple. Here, we can take the reconstruction record in 1614 as a case study. According to the "Chongxiu Dongzhen Yishanmiao ji" 重修東鎮沂山廟記 (Account of Rebuilding the Yishan Temple of the Eastern Stronghold) by Zhao Bingzhong 趙秉忠, the Eastern Stronghold Temple had once again fallen into a state of disrepair for an extended period of time (Zhang 2009, pp. 186-87; Zhao and Gong 2011, p. 87). In 1611, Ma Youchun 麻友椿 served as the governor of Linqu County, and when he offered sacrifice to the Eastern Stronghold Temple in autumn of that year, he found the temple dilapidated and hoped to repair it, but he was unable to support the production by himself and the county office alone. Later, under the petition of the local Confucian scholar Chen Zhigong 陳致 恭, the elder aristocrat Wang Laipin 王來聘 and some other local gentry, the Linqu government and the local forces launched the fund-raising and reconstruction work 
together. Due to a fortunate acquisition of giant woods for construction, the main hall was rebuilt within three months, and then the dormitory, bell, and drum towers, and other buildings were also restored. The reconstruction of the Eastern Stronghold Temple from this time is most obviously seen from the signatures on the back of the stele, which acknowledge the successful tripartite cooperation of local officials, Daoists, and folk forces. On the back of the stele, there are several clear categories on the donor list including the names of local aristocrats, Confucian scholars, officials, local elders, craftsmen, three temple abbots, and 33 ordinary Daoists.

\subsection{The Constructions in 1663 and 1701 of the Qing Dynasty}

When the Qing Dynasty replaced the Ming Dynasty, the temples of sacred peaks, strongholds, seas, and waterways were made into a symbol of the Qing Empire's ruling legitimacy and orthodoxy and their sacrificial rituals were paid attention to by the new government. As far as the Eastern Stronghold is concerned, from the description of "Li Rui daisi Dongzhen Yishan bei" 李荵代祀東鎮沂山碑 (Stele of Sacrifice to Mount Yi the Eastern Stronghold Hosted by Deputy Li Rui), we can see that by the third year of Shunzhi 順治 (1646) at the latest, the Qing court began to send envoys to worship Yishan at the Eastern Stronghold (Zhang 2009, p. 429). However, the first large-scale renovation of the Eastern Stronghold Temple during the Qing Dynasty did not begin until the second year of Kangxi (1662), and the temple-guarding Daoist priests once again played important roles in the project.

There are two original accounts of reconstruction activities in that very year, both written by Zhang Yinli 張印立, a Presented Scholar of Linqu County, namely, “Chongxiu Dongzhen Yishanmiao ji” 重修東鎮沂山廟記 (Account on the Reconstruction of Mount Yi the Eastern Stronghold Temple) and "Chongxiu Dongzhenmiao luocheng ji" 重修東鎮廟落成記 (Account on the Completion of the Eastern Stronghold Temple). The "Account on Reconstruction" might have been written before the reconstruction project in 1662. It was emphasized in the stele that "the duty of the local government is to govern the people and sacrifice to the gods" 治民事神, 司土之责. That autumn, when the county magistrate Xie Cimu 謝賜牧 offered sacrifice to the Eastern Stronghold, the main hall of the temple began to leak and was drenched in rain, so the magistrate summoned the Daoist Zhu Quanzhou 朱全用 to propose a plan to rebuild it. At this time, they found that not only the main hall but also the dormitory hall and two affiliated halls needed to be repaired, and the Dragon Pavilion and Pavilion for Killing Sacrificial Victims had both been ruined as well (Yin 2002, 4.95). "Account on the Completion", written after the reconstruction, also mentioned the wish of Xie Cimu to renovate the temple in the autumn of 1662. The following spring (1663), Xie Cimu sacrificed in the Eastern Stronghold Temple to pray for rain to alleviate the drought. As soon as he finished the ritual, it began to rain. On this occasion, Xie Cimu formally proposed the reconstruction plan and took the lead in donating one-hundred-and-thirty gold coins, while other officials and the local elder gentry also responded positively to the call for donations. The reconstruction was proposed in the ninth month of 1662 and ended in the tenth month of 1663 . According to the inscription, more than 50,000 tiles were added to the old temple, 70,000 jin (Approx. $4178 \mathrm{~kg}$ ) of mud were used, and more than 1000 roof rafters were replaced. Finally, the temple became as clean as the Confucius Temple. The Dragon Pavilion and the Pavilion for Killing Sacrificial Victims were also renewed. The statue of the Sea God (haishen 海神) was restored and now solemnly stands in the hall with neat clothes and holding a ritual scepter (Zhao and Gong 2011, p. 92).

The following records describe in detail the efforts made by the Daoist priests in the temple to rebuild the Eastern Stronghold Temple and at the same time show the complex relations between these Daoist priests. According to Zhang Yinli, a Daoist priest surnamed Cao 曹 in the Eastern Stronghold Temple hired people to dig outside the temple gate and found thousands of kilograms of lime. Cao in vain tried 
to keep this a secret, but eventually the news leaked to everyone, yet none of the Daoists dared to be the first to reveal it. As a result, in the third month of 1663, the constructing supervisor ordered to dig the lime out, even though Cao denied it. Cao was probably Cao Zhenwei 曹真惟, whose name appeared in the Daoist signatures of “Chongxiu Dongzhen Yishan miao ji” 重修東鎮沂山廟記 (Record of Rebuilding the Temple of Yishan the Eastern Stronghold) in 1614. In Zhang Yinli's record, there was another episode: in Niujiagou 牛家溝 village, Linqu County, a villager called Niu Si 牛四 had a big poplar tree in his own cotton yard. Daoist priests advised him several times to donate the tree for the reconstruction of the Eastern Stronghold Temple but Niu refused. Soon thereafter, Niu became seriously ill and his family donated the big poplar tree, but Niu did not recover in the end. From the above records, the temple-guarding Daoists raised funds through local folks to support the reconstruction projects.

Thirty-eight years later, the Eastern Stronghold Temple was renovated again. According to "Chongxiu Dongzhen miao beiji" 重修東鎮廟碑記 (Stele Record of Rebuilding the Eastern Stronghold Temple), written by Chen Tingwan 陳霆萬 in 1701, the Temple was in a dilapidated condition once again. In 1697, Zhang Zengyu 張 曾裕, the county magistrate of Linqu, planned to repair the temple and "summoned Daoists to raise money" 召黃冠為疏以募資 (Zhao and Gong 2011, p. 101). However, Zhang left office soon after in order to observe the mourning rites for his deceased mother. His successor Chen Tingwan, was the one who completed the project. According to Chen Tingwan, the essential works can largely be attributed to the director Daoist Wang Zhengwei 王正位. According to this stele, Wang was the abbot of the Eastern Stronghold Temple at this time. In 1702, there was another building activity in the Eastern Stronghold Temple. According to the "Chongxin Dongzhen shenxiang ji" 重新東鎮神像記 (Record of Remaking the Statue of the Eastern Stronghold God) by Chen Weiyin 陳維寅, the local Education Supervisor, when the idol figure in the temple was found to be defective, someone proposed to use the wooden name tablet to replace it. However, most of local people had a negative view of this plan because they believed that only a new statue could arouse the piety of ordinary people. So, under the leadership of two elder aristocrats, Zong Kai 宗炌 and Zhang Jie 張捷 of the local folk association, the idol statue was rebuilt (Zhao and Gong 2011, pp. 103-4). By the end of the record, the signatures show that, in addition to the local community, those who participated in the construction of the statue also included Xu Hefeng 徐 和風, Liu Wuxiang 劉無祥, and other Daoist priests. A passage in this inscription provides us with a clue for local forces to enter the temple. It reads:

The god of Mount Yi presided in the East, the sons of Heaven (the emperors) always send officials to offer sacrifices, and the relevant governmental institutes greet him every Spring and Autumn. No matter whether there are floods, droughts, or epidemics, the god always answer prayers' requirements. Thus, the temple is crowded with those who come here for incensepraying and ritual offering from near and far. 況沂山之神 $\square$ 鎮東方, 天子遣 官致祭, 有司春秋告祀, 水旱口疫, 有禱必應, 遠近進香設醮者, 絡繹而至. (Zhao and Gong 2011, p. 103)

Regarding how the Eastern Stronghold Temple was to be used, not only did the government have a set of etiquette regulations for offering sacrifices but the folk groups, also, always kept their own rituals with regular belief practices, including incensepraying and ritual offerings. Some materials show that spring and autumn temple fairs appeared in Mount Yi during the Qing Dynasty or even earlier (Pan 1998, p. 19). While according to the remaining steles of "Renshouxiang Panyangshe xiujiao canbei" 仁壽鄉盤羊社修醮碑 (Fragmentary Stele of Offering Ritual by Panyang Community in Renshou Township) (Zhao and Gong 2011, p. 132), “Quqiu Bolizhuang beiji” 渠丘 泊里莊碑記 (Stele Record of Quqiu Boli hamlet) (Zhao and Gong 2011, p. 96; Zhang 2009, pp. 205-7), and Notes of The Eastern Stronghold (Zhang 2009, p. 205), during the 
Kangxi reign, at the latest, the folk people were led by Daoist priests to set up festival offerings within the Eastern Stronghold Temple.

According to integrated studies on the constructions of the Eastern Stronghold Temple in generations (beyond the above cases), it is known that the central courts always showed some enthusiasm for the reconstruction and maintenance of the Eastern Stronghold Temple at the beginning of the establishment of the Yuan, Ming, and Qing dynasties. This was probably because the Eastern Stronghold, as one of the sacrificial sites, symbolized the ruling legitimacy of the new dynasty. The measures to revitalize the Eastern Stronghold Temple were directly involved in the public performance promoting the destiny of the new dynasty. However, with the downward movement of the dynasty, official maintenance of the Eastern Stronghold Temple became less and less adequate, as can be noticed most prominently in the Ming and Qing dynasties. Although there were objective reasons for the neglect of the Eastern Stronghold Temple by the authorities (whether central or local), a deeper cyclical reason might be that when dynastic rule stabilized, the court would naturally pay less attention to the beliefs about the legitimacy of its governance. At the same time, the Daoist priests in the Eastern Stronghold Temple encountered the awkward situation of neither getting full support from the authorities nor easily being able to give up such a large-scale temple. Finally, they were forced to bear the responsibility for the daily operation of the temple to a large extent on their own. In order to maintain the Eastern Stronghold Temple and to maintain their own livelihood, the Eastern Stronghold Daoist priests sought more resources and cooperation from local society. As a result, the Daoists in the Temple gradually lost their "official identity" but transformed into the representatives of "local society".

When official power diluted in the management and control of the Temple, Daoists obtained and expanded the operational authority of the Eastern Stronghold Temple by constantly participating in and presiding over the construction of it. From then on, the temple was not only a place for the spring and autumn sacrifices of the imperial court, and a place for local officials to ask for rain, it also became a general worshiping space for Daoism and folk shrines. It seems that there was a game of "rights and obligations" between the imperial officials and the "folk forces" represented by Daoist priests guarding the temple and giving up obligations was tantamount to the transfer of rights. As a result, the Eastern Stronghold Temple had the dual function of being both a place of official sacrifice and a Daoist-folk temple where the official etiquette in the temple went hand in hand with Daoist-folk rituals, although the two kinds of ceremonial activities did not occur simultaneously.

\section{Conclusions}

Through meticulous research of the literature, the true history of an important national temple in northern China was retraced by analyzing a number of stele materials. The daily state of the Eastern Stronghold temple presented in the study was completely different from the general expectation of this kind of temple as a "pure place of national sacrifice". We find that under the operation of Complete Perfection Daoist priests, the Eastern Stronghold Temple as a national sacrificial temple had complex entanglements with the local society and beliefs.

As shown in this article, the multiple nature and functions of the Eastern Stronghold Temple had not yet appeared when the temple was first established but were the result of gradual coordination throughout the developing history with the exchange and operation of different people. In the context of the changes from the Yuan Dynasty to the Qing Dynasty, the Eastern Stronghold Temple is intertwined with a variety of opposing relations: national sacrifice and Daoist guarding, officials in the background and folk operation, etiquette regulations and local expediency, and so forth. As different people had different intentions when it came to care, operation, and participation, the temple presented a variety of cultural significance and social functions. 
As a result, these seemingly opposing phenomena could be presented separately in the same temple.

Through interpretation of the existing steles and other materials, we have completed the reconstruction of the historical changes of the Eastern Stronghold Temple, and some cases which were most closely related to the guardian Daoists have been presented. It is not difficult to discover that, although disputes and struggles between different discourse and power systems might have arisen over the retention or abolition of an idol, more often than not, cooperation could still be reached among the officials, Daoists, folk people, and other forces, each taking what they needed. At the same time, under the superficies of cooperation, there was a game of transferring obligations and power between the Daoists and the authorities. In such a staggered interaction, the Daoist priests played various roles. Obviously, Daoists were not "outsiders" who had nothing to do with this world but rather acted as "pragmatic" religious groups who spread their influence to all levels of society through various ways and means. They not only had a special network of religious life and social relations special to them as Daoists, they also became the actual executors of the daily operation of the Eastern Stronghold Temple through faithful actions.

In the dynamic communication, the authorities and the local forces represented by Daoists reached a tacit consensus that the government owned this sacred temple at the level of the imperial ritual system and symbolism, but Daoists and local people gained greater power of interpretation and use of the temple at the practical level. The national sacrificial temples, which were originally set up by the imperial government, could only be maintained with the support and collaboration of folk forces. The local forces, including Daoists and the common people, did not fully accept the interpretation of the temple system and meanings stipulated by Confucian and state ideology but tried to incorporate other beliefs and practices while participating in temple activities. Thus, the nominal national sacrificial temple also became at the same time a Daoist abbey and a folk temple in the local society.

Finally, it is worth noting how the actual operation of national beliefs were promoted by the imperial governments at the local level. This study has relevant reference value for understanding the central-local government relationship in ancient China, the political-religious relationship between the national belief and Daoism, and relations among the local society more generally. That having been said, for all the progress that has been made, further questions regarding the Eastern Stronghold Temple remain open and will require further efforts in the future.

Author Contributions: Conceptualization, Z.B. and T.Y.; methodology, Z.B.; validation, Z.B. and T.Y.; formal analysis, Z.B.; investigation, Z.B.; resources, Z.B.; data curation, Z.B.; writing-original draft preparation, Z.B.; writing—review and editing, T.Y.; supervision, Z.B. All authors have read and agreed to the published version of the manuscript.

Funding: This research received no external funding.

Institutional Review Board Statement: Not applicable.

Informed Consent Statement: Not applicable.

Data Availability Statement: Not applicable.

Conflicts of Interest: The authors declare no conflict of interest.

\section{References}

Cheng, Yue 程越. 2012. Jinyuan shiqi quanzhen dao gongguan yanjiu金元時期全真道宮觀研究 [Study on Halls and Temples of Complete Perfection Daoism in Jin-Yuan Dynasties]. Jinan: Shandong Qilu Press.

Feng, Weimin 馮惟敏 (1511-1578) etc. 2014. Jiajing Qingzhoufu zhi嘉靖青州府志 [Gazetteer of Qingzhou Compiled in Jiajing Period Ming Dynasty]. In Tianyige cang mingdai fangzhi xuankan天一閣藏明代方志選刊 [Gazetteers of Ming Dynasty Reserved in Tianyege]. Shanhai: Shanghai Shudian, vol. 56. 
Fu, Guo 傅國 (1576-1644). 2003. Changguo yuhuang 昌國艅艎 [Great Voyage of Changguo]. In CPPCC Linqu Committee 中國人民 政治協商會臨朐委員會 ed., Linqu Xian Jiuzhi Xubian 臨朐縣舊志續編 [Sequel of Old Gazetteers of Linqu]. Linqu: Shandongsheng Xinwenchubanju, pp. 1-119.

Jia, Jinhua. 2021. Formation of the Traditional Chinese State Ritual System of Sacrifice to Mountain and Water Sprits. Religions 12: 319 [CrossRef]

Liang, Yong 梁勇. 2013. Zhenmiao jianzhu yu jisi yanjiu鎮廟建築與祭祀研究 [Research on Temples and Sacrifice for Chief Mountains]. Master's Dissertation, Southeast University, Nanjing, China.

Lin, Qiaowei 林巧薇. 2017. Shilun Songshan zhongyue miao yu song yihou guojia jisi lizhi de guanxi試論嵩山中嶽廟與宋以後國家 祭祀禮制的關係 [On the Relations between Zhongyue Temple in Songshan Mount and the National Ceremony after the Song Dynasty]. Shijie zongjiao wenhua世界宗教文化 [The World Religious Cultures] 3: 105-11.

Liu, Kangle 劉康樂. 2017. Mingdai daoguan zhidu yu shehui shenghuo明代道官制度與社會生活 [Daoist Official System and Social Life in Ming Dynasty]. Beijing: Jincheng Chubanshe 金城出版社.

Ma, Xiaolin 馬曉琳. 2011. Difang shehui zhong guanfang cimiao de jingji wenti: yi yuandai Kuaijishan Nanzhen miao wei zhongixin地 方社會中官方祠廟的經濟問題 : 以元代會稽山南鎮廟為中心 [Economy of Official Temple in Local Society: Focus on Nanzhen Temple in the Kuaiji Mountain in Yuan Dynasty]. zhongguo shehui jingji shi yanjiu中國社會經濟史研究 [The Journal of Chinese Social and Economic History] 3: 12-17.

Pan, Xinde 潘心德, ed. 1998. Dongzhen Yishan 東鎮沂山 [Mount Yi the Eastern Stronghold]. Jinan: Jinan Chubanshe.

Qin, Guoshuai 秦國帥. 2014. Shandong quanzhenjiao de jiaotuan guimo, fenzhi chapai yu diyu fenbu (1368-1949) 山東全真教的教團 規模,分枝岔派與地域分佈 (1368-1949) [The Size, Branch Schools and Regional Distribution of Complete Perfection Daoism in Shandong Province (1368-1949)]. In Quanzhendao yanjiu全真道研究 [Studies on Complete Perfection Daoism]. Edited by Weidong Zhao 趙衛東. Jinan: Shandong Qilu Press, vol. 3, pp. 188-247.

Qingzhou Prefecture Authority, Shandong Province 山東省青州府. 2003. Linquxian fuyi quanshu 臨朐縣賦役全書 [Comprehensive manual of Linqu taxes and corvée]. In Linqu Xian Jiuzhi Xubian 臨朐縣舊志續編 [Sequel of Old Gazetteers of Linqu]. Edited by CPPCC Linqu Committee. Linqu: Shandongsheng Xinwenchubanju, pp. 211-34.

Ren, Wenbiao 任文彪. 2019. Collated. Dajin jili大金集禮 [Collection of Rituals of Great Jin Dynasty]. Hangzhou: Zhengjiang University Press.

Toqhtō 脱脱 (1314-1356) etc. 1975. Jinshi金史 [History of Jin]. Beijing: Zhonghua Book Company.

Wang, Jiashi 王家士 (fl. 1552). 2002. Jiajing Linquxian zhi 嘉靖臨朐縣誌 [Linqu Gazeteer complied in Jiajing period Ming dynasty]. In Linqu Xian Jiuzhi Huibian 臨朐縣舊志彙編 [Compilation of Old Gazetteers of Linqu]. Edited by CPPCC Linqu Committee. Weifang: Weifangshi Xinwenchubanju, pp. 1-39.

Wang, Juyi 王居易 (fl. 1586). 2003. Dongzhen Yishan zhi東鎮沂山志 [Gazeteer of Mount Yi the Eastern Stronghold]. In Linqu Xian Jiuzhi Xubian 臨朐縣舊志續編 [Sequel of Old Gazetteers of Linqu]. Edited by CPPCC Linqu Committee. Linqu: Shandongsheng Xinwenchubanju, pp. 120-68.

Wang, Zongyu 王宗昱, ed. 2005. Jinyuan Quanzhen jiao shike xinbian 金元全真教石刻新編 [New Compilation of Stone Inscriptions of Complete Perfection Daosim in Jin and Yuan Dynasties]. Beijing: Beijing University Press.

Yao, Yanfu 姚延福(fl. 1905). 2002. Guangxu Linqu xianzhi 光緒臨朐縣誌 [Linqu Gazeteer complied in Guanxu period Qing dynasty]. In Linqu Xian Jiuzhi Huibian 臨朐縣舊志彙編 [Compilation of Old Gazetteers of Linqu]. Edited by CPPCC Linqu Committee. Weifang: Weifangshi Xinwenchubanju, pp. 113-363.

Yin, Suolin 尹所遴 (fl. 1672) etc. 2002. Kangxi Linquxian zhi 康熙臨朐縣誌 [Linqu Gazeteer complied in Kangxi period Qing dynasty]. In Linqu Xian Jiuzhi Huibian 臨朐縣舊志彙編 [Compilation of Old Gazetteers of Linqu]. Edited by CPPCC Linqu Committee. Weifang: Weifangshi Xinwenchubanju, pp. 40-112.

Zhang, Dunren 張敦仁 (fl. 1726-1733). 2003. Linqu biannian lu 臨朐編年錄 [Chronile of Linqu]. In Linqu Xian Jiuzhi Xubian 臨 朐縣舊志續編 [Sequel of Old Gazetteers of Linqu]. Edited by CPPCC Linqu Committee 中國人民政治協商會臨朐委員會. Linqu: Shandongsheng Xinwenchubanju, pp. 169-210.

Zhang, Xiaoyou 張孝友, ed. 2009. Yishan shike 沂山石刻 [Stone Inscriptions of Mount Yi]. Jinan: Shandong Friendship Publishing House.

Zhang, Mu 張目. 2011. Gudai guojia zhenshan jisi geju chutan古代國家鎮山祭祀格局初探 [The Structure Investigation on Sacrifice of Ancient National Chief Mountains]. Master's Dissertation, Jinan University, Guangzhou, China.

Zhang, Jinghua 張敬華, and Xuan Wang 王萱. 2001. Dongzhenmiao beilin shike dangan 東鎮廟碑林石刻檔案 [Stone Carving Archives of Stele Forest in Eastern Stronghold Temple]. Shandong Dangan 山東檔案 [Shandong Archives] 4: 41-42.

Zhao, Weidong. 2014a. Haotian gong de chuangli jiqi zongpai chuancheng 昊天宮的創立及其宗派傳承 [Establishment of Haotian Temple and its sectarian inheritance]. Zongjiaoxue yanjiu宗教學研究 [Religious Studies] 4: 1-8.

Zhao, Weidong. 2014b. Yishan dongzhenmiao jiqi zongpai chuancheng 沂山東鎮廟及其宗派傳承 [Eastern Stronghold Temple of Mount Yi and its sectarian inheritance]. In Quanzhendao yanjiu全真道研究 [Studies on Complete Perfection Daoism]. Edited by Weidong Zhao. Jinan: Shandong Qilu Press, vol. 3, pp. 167-88.

Zhao, Lei 趙否. 2020. Tangsong shiqi yuezhenhaidu guanli yanjiu: yi “miaoling” wei zhongxin 唐宋時期获鎮海瀆管理研究—以“廟 令”為中心 [Research on Management of Mountain and Sea Temples in Tang and Song Dynasty-Temple Orders Centered]. Shanxi datong daxue xuebao 山西大同大學學報 [Journal of Shanxi Datong University] 2: 51-55.

Zhao, Weidong, and Dejie Gong 宮德杰, eds. 2011. Shandong daojiao beike ji: linqu juan山東道教碑刻集.臨朐卷 [Collection of Daoist Inscriptions in Shandong: Linqu]. Jinan: Shandong Qilu Press.

Zhao, Weidong 趙衛東, and Mingjun Zhuang 莊明軍, eds. 2010. Shandong daojiao beike ji: qingzhou, changle juan山東道教碑刻集·青州昌 樂卷 [Collection of Daoist Inscriptions in Shandong: Qingzhou and Changle]. Jinan: Shandong Qilu Press. 